\title{
Ethical Investment and the Social Responsibilities of the Islamic Banks
}

\author{
ELMELKI Anas (Corresponding author) \\ High Institute of Management, Research and Teaching Associate ISAEG \\ The High Institute of Business Administration of Gafsa Tunisia \\ B.P 53 Gafsa Gare 2111 Tunisia \\ E-mail: Elmelki-anes@laposte.net \\ BEN ARAB Mounira \\ University of Tunis High Institute of Management, ISG Tunisia \\ E-mail: mounira_benarab@yahoo.fr
}

\begin{abstract}
While ethics and financial investments seem to be mutually exclusive, ethics have recently become an important issue in the financial field. There is an increased emphasis on the role of faith and religious beliefs on ethical business practices for some investors who not only seek profits through their investments but they also require the achievement of a moral duty beside the quest of wealth accumulation.

Since investors become more aware of the benefits of Ethics and socially responsible investment, the interest in Islamic investing and ethically based banking is also increasing.

Among the most important objectives of the Islamic finance in general and particularly the Islamic banks, is the establishment of justice and elimination of exploitation in business transaction. This can be done by the prohibition in of all sources of illegal "unjustified" enrichment and the prohibition of dealing in transactions that contain excessive risk or speculation. The paper seeks to explain that the Islamic bank services represent an example of ethically and socially responsible investment.
\end{abstract}

Keywords: Ethical investment, Social responsibility, Islamic banking, Poverty alleviation

\section{Introduction}

Generally investment decisions are based solely on financial criteria such as risk and returns. However, over the last few years many investors have started taking into account a new dimension, that is, the ethical nature or, more generally, the social responsibility attached to their investments.

If the role played by the religion and spirituality in the modern world is weak, it would be because other forces have squeezed them out, either assuming their role or making fulfilment of their purpose impossible.

There are an increasing number of investors who seek to align their investments with their principles through ethical and socially responsible investment.

Ethics are a set of values and principles accepted by any person or a group. Religion is seen as playing an important role in determining these values and principles, in shaping personality and behaviour of individuals, in particular on some aspects of investment decision-making.

Ethical practices, in the Islamic banking framework, are derived from religious teaching. Islamic banking is one form of integrating religious principles in investment decisions. The basic tenet of Islamic banks is that the investor should invest his or her assets to reflect the Islamic principles that govern his or her daily life.

In the following, the terms 'ethical investments' and 'socially responsible investments' are used interchangeably.

The paper is organized as follows. In section 2 we give a quick review of the phenomenon of ethical investment followed by a short definition of what is Ethics, with some explanation of Ethics in Islam. In section 3 we clarify the Relationship between ethical investment and Islamic principles. We then attempt to identify the essential foundations of the Islamic Banks and its principles with an emphasize on the Social role and Social Effects of Islamic Banking.

\section{The phenomenon of ethical investment}

The concept of ethical investment is based on the philosophical, religious or moral convictions of individual or collective investors, who exclude from their investment universe all stocks in fields which they consider contrary to their convictions. 
Ethical investing is growing phenomenon; it deals with the questions of what is considered to be right and what is wrong.

In an economic context, ethical investments are meant to achieve monetary gains and outcomes, however it relies much more on some other objectives different from those guided only by maximizing the expected utility from pecuniary wealth or income (Note1).

Ethical investors are firstly concerned about the characteristics of the companies in which the funds are placed and then about the financial returns on their portfolios and the risks involved. This is essentially due to the "feel good" factor for those investors, which can make them having a good conscience about the returns on their assets.

The motivations for Ethical and socially responsible investment could have two sources. Subjective source are linked to personal ethics, to the application of superior moral principles with which there can be no compromise.

As for the objective motivations, they reflect apprehension about the social losses or gains arising from the firm's activities (for example pollution, smoking, work-related illnesses, etc.) (Note 2).

It should be possible, theoretically, to define an ethical investment objectively on the basis of the criteria used to select investment. Ethical investment can result from negative screening. It's most common form is the selection of an investment universe which excludes companies that operate in what are considered to be "sinful" industries: companies implicated in the production of alcohol, tobacco, nuclear energy or gambling for example. Negative screening can also exclude companies based in countries in which the political regimes do not guarantee fundamental human rights

Ethical investment can also be the result of positive screening by selecting an investment universe based on good practices in a particular field, such as in human rights or the protection of the environment, for example. Some investment universes result from the combination of both negative and positive screening (Note 3).

\section{What is Ethics?}

Ethics is a set of moral principles that distinguish what is right from what is wrong. Ethics evaluates human practices by calling upon moral standards; also it may give prescriptive advice on how to act morally in a given situation.

\subsection{Financial Ethics "invest your money where your values are"}

Financial Ethics is the branch of Ethics that examines ethical rules and principles within the financial context; the various moral or ethical problems that can arise in a business setting; and any special duties or obligations that apply to persons engaged in commerce. Generally speaking, business ethics is a normative discipline, whereby particular ethical standards are formulated and then applied. It makes specific judgments about what is right or wrong, which is to say, it makes claims about what ought to be done or what ought not to be done. Generally speaking, business ethics is concerned with the study of what is good and bad, right and wrong, and just and unjust in business (Note4). Ethical investing has ancient origins and is rooted in religious traditions Jewish, Christian, and Islamic teachings.

\subsection{Ethics in Islam}

All the monotheistic religions have their own sets of divine values and norms with regard to human behaviour, in particular economic behaviour.

Islam has very clear prescriptions about how business should be done with special focus on the social and ethical dimensions of business.

Islam requires Muslims to lead their lives according to the Islamic legal code of 'Shariah' that Muslims worldwide are expected to follow to the extent possible given their circumstances. The Shariah, or divine guiding principles, is the Islamic law of human conduct which regulates all matters of the lives of Muslims. It is based on God's holy word in the Qur'an, the deeds and sayings of the prophet Mohammed (Sunah), and the consensus of Islamic religious scholars).

Islam places the highest emphasis on ethical values in all aspects of human life. In Islam, ethics governs all aspects of life.

Islamic teachings strongly stress the observance of ethical values and moral principles in human behaviour which are repeatedly stressed throughout the Holy Qur'an and the numerous teachings of the Prophet (PBUH).

The most important of the basic Islamic values of life are the believe in the existence of God-the creator, temporary life on earth, accountability of all actions on the Day of Judgment, and reward by the All-Aware according to the real motive of every human action. Among the principle pillars of an Islamic society are love and fear of God, honesty, and justice (Note5).

Islamic finance flows from the principle that religion cannot be divorced from any aspect of life, including business.

The business relations in the Islamic framework are mainly ethics based originating from religious beliefs, trust and faith. Religious norms/values and beliefs are supposed to regulate human behavior in society. 
The Islamic finance embraces the philosophy of risk sharing, ethical and religious goals, including a quest for justice, and the promotion of social and economic welfare which extends beyond profit maximization.

\section{Relationship between ethical investment and Islamic principles}

All the religions share the same basic purpose, Socio-economic justice. In an Islamic framework, an individual not only lives for himself, but the range of his activities and responsibilities extend beyond him to the welfare and interests of society at large.

In Islam, the rights and obligations of individuals and organizations with respect to others are clearly defined by religion, this is considered to make Islam a stronger and more effective basis for ethical values. Despite the presence of many schools of thought in Islam, there is agreement on basic matters of principle. Responsibilities of members of society to each other are well defined, do not change over time and are not affected by different theoretical frameworks.

In the Islamic context, the ethical investments and the social responsibilities of individuals that are derived from the Shariah, also apply to firms. Similarly, the main purpose of an Islamic business is to satisfy the will of God, through following the Islamic teachings. Islam considers work to be part of the worship of God.

Islamic ethics are based essentially on its conception of man in relation to God, his own self, the universe and the Society.

According to Islamic law an individual has the right to get return for utilizing his/her capital in an economic venture, but the issue is how it can be acquired.

It is legal for a business to achieve profits, but this goal should be pursued according to Shariah. Since Shariah defines the norms of human conduct, and how business has to deal with its external environment, businesses claiming to comply with Shariah should be clearer about their roles in society. Social justice and ownership are central to social relations.

Islam stresses the concept of social responsibility. All Muslims are considered to be brothers and should take care of each other, and no cheating or exploitation is allowed, whatever the reasons.

Islamic ethics create a sense of responsibility and accountability in the mind of the believer who must be guided by conscious purposes.

The Islamic perspective concerning social responsibility and justice has implications on business practices. The fundamental codes of moral behavior involve truthfulness, trustworthiness, generosity and leniency, fair treatment of workers and avoidance of evil practices such as, interest (Riba), fraud, cheating, deceit, exploitations, etc. in accordance to the Islamic jurisprudence concerning the lawful and unlawful which are the crucial elements of social responsibility and justice in Islam.

The permissible range of choices of Islamic investment is wide. It involves investments in companies and businesses which undertake to deploy funding on a permissible "halal" basis, these include interest free bank deposits. Investments to be avoided and regarded as haram include conventional bank savings and investment deposits, the purchase of interest yielding bonds, and the acquisition of shares in companies involved in alcohol production or distribution or in pork products.

\section{Islamic Banking: An Overview}

The choice of the Islamic banks, as a case of study of the ethical investment, can be justified by the fact that Islamic banking is an essential component of everyday Muslim business life. Islamic banks perform in accordance with the conscience or practical interests of believing Muslims. They are similar to socially responsible funds in the west. It is thus felt that the research will make a useful contribution to the Ethical Investment theory and practice. The Islamic banks constitute a highly prominent sector in the Islamic finance. Already operating at a global level, the Islamic banking system is currently spreading fast throughout the world.

Its success is indicated by the rapid growth in number of banks, branches, accounts, and sums of money it handles. Western glorious conventional financial institutions such as Citigroup, HSBC, JF Morgan, Barclays, Kleinwort Benson, Deutsche Bank, Lloyds, JP Morgan, Royal Bank of Scotland, Algemene Bank Nederland (ABN) AMRO, Goldman Sachs, American Express, ANZ, Grindlays, United Bank of Switzerland (UBS), Commerzbank, Société Général and BNP Paribas have started introducing interest-free products to their customers.

Banking is one of the most sensitive businesses all over the world. Banks play a very positive and important role in the economy of a country.

Like any conventional bank, an Islamic bank is a financial intermediary and trustee of people's money with the difference that the Islamic banks reject the receipt and payment of interest on any of its operations. This prohibition of dealing with the interest rate leads them to payoff to all its depositors a share in profits and losses. This difference 
introduces an element of mutuality in Islamic banking, making its depositors as customers with some ownership rights inherent within it.

Islamic banks provide investment and financing activities for Muslims who are keen to adhere to Islamic law in their business transactions; Islamic banks also offer their clients a variety of financial products that are in accordance with Shariah.

What distinguish an Islamic bank from a conventional one is that the Islamic bank keeps in view certain social objectives intended for the benefit of society. The Islamic banks aim to establish distributive justice free from all sorts of exploitation. From the Islamic point of view, business transactions can never be dissociated from the moral objectives of the society.

Islamic banking aims the social justice through forbidding all forms of economic activities which are morally or socially injurious, ensuring ownership of wealth legitimately acquired, allowing an individual to retain any surplus wealth and seeking to prevent the accumulation of wealth in a few hands to the detriment of society as a whole through its laws of inheritance.

Islamic banks are mainly concerned about justice and fairness and prohibit the extracting of a surplus value in an unfair way through the practice of paying and receiving interest regardless of the purpose for which loans are made and the rates at which interests are charged.

\subsection{Principles of Islamic banks}

The goals of the Islamic finance are not mainly materialistic but are based on the concepts of human well being and achieving a good life overall. It emphasise on community values, socio-economic justice and a balance between the material and spiritual needs of its followers.

The main principles of Islamic banks include:

$>$ The prohibition of taking or receiving interest: Financial transaction should be free from interest (Riba) and directly or indirectly linked to a real economic transaction. Profit from indebtedness or the trading of debts is seen to be unethical. Profit from indebtedness or the trading of debts is seen to be unethical. Instead, the investor and investee should share in the risks and profits generated from a venture, an asset or a project.

The prohibition of interest "Riba" (Note 6) is the central tenet of the Islamic economy. This prohibition is based on arguments of social justice, equality and property rights. Interest, according to the Islamic view, violates the principle of social justice, in that it rewards people who neither make an effort nor participate in the risks of the projects financed.

The Holy Qur'an prohibits the charging and the payment of interest. Technically, Riba refers to the addition in the amount of the principal of a loan according to the time for which it is loaned with the amount of the loan.

Islam is not against the earning of money, but it prohibits the earning of money through unfair trading practices and other socially harmful activities.

Islam seeks to build up an economic environment based on fairness and justice through the prohibition of interest "Riba". From an Islamic point of view, it is much fairer that the provider of funds shares the profits and the losses with the entrepreneur (borrower) than the receipt of a fixed return provided by the loan to the lender regardless of the outcome of the project. The idea of fairness in this situation has more than one dimension. The provider of capital has the right to a return, but this return should be equivalent to the risk and effort involved in the project for which the finances are supplied. Therefore, the Shariah prohibits not fixed returns but predetermined returns.

$>$ A financial transaction should not lead to the exploitation of any party of the transaction; parties to a financial contract should share in the risks and rewards derived from such financing or investment transaction.

$>$ The ban on unlawful assets: no financial transaction should be directed towards economic sectors considered unlawful such as investments in businesses dealing with tobacco, alcohol, gambling industries, drugs, harmful substances, pork as well as all enterprises for which financial leverage (indebtedness level) would be deemed excessive (including conventional financial activities) or anything else that the Shariah considers unlawful are deemed undesirable and prohibited "haram" or sinful activities(Note 7).

$>$ Prohibition on transactions involving Maiser (speculation or gambling); and a prohibition on gharar, hazardous or excessive ambiguity in transactions or uncertainty about the subject-matter and terms of contracts - this includes a prohibition on selling something that one does not own. The financial transactions involving elements of speculation are forbidden, such as purchasing goods and services at a low price and selling them for a higher price in the future. This is due to the fact that speculators generate their profits at the expense of the society at large. Thus, speculation, which necessary entails artificial risk in any market be it in money, gold, commodities and the like, is not permissible in an Islamic setting. 
> Islamic business principles include respect for the environment and human welfare, fair and transparent dealing, and fair and just employment.

$>$ Any financial transaction should be based on a tangible, identifiable underlying asset.

\subsection{How does an Islamic bank differ from a non-Islamic bank?}

Unlike conventional banks, Islamic banks objectives should include social dimensions. Capital must have social and ethical purposes beyond pure, unfettered return. The moral principles and objectives play a more important role in the operations, missions and objectives of an Islamic bank than in a non-Islamic bank.

Islamic banks have an Islamic (religious) board, to ensure that the bank's practices are in line with the Shariah, and a strong social solidarity division.

\subsection{The Shariah board:}

One distinct feature of the modern Islamic banking movement is the role of the Shariah board, which forms an integral part of an Islamic bank. A Shariah board monitors the workings of the Islamic bank and every new transaction that is doubtful from a Shariah standpoint has to be cleared by it. These boards include some of the most respected contemporary scholars of Shariah and the opinions of these boards are expressed in the form of fatwas. In addition, the International Association of Islamic Bankers, an independent body, supervises the workings of individual Shariah boards while its Supreme Religious Board studies the fatwas of the Shariah boards of member banks to determine whether they conform to Shariah. Shariah law is open to interpretation and Shariah boards often have divergent views on key Shariah issues. In this regard, there is no practical guide as to what constitutes an acceptable Islamic financial instrument. A document or structure may be accepted by one Shariah board but rejected by another Shariah board.

The board should not include directors or significant shareholders of either the sponsor or the bank manager.

The selection of respected members of the community is essential because this board will bring reputation and credibility to the bank.

Broadly speaking, the three key functions of Shariah boards are:

- $\quad$ To provide advice to Islamic bank;

- To supervise and audit transactional procedures of Islamic bank; and

- To supervise and actively participate in the creation of innovative Shariah compliant investment and financing products and services.

\subsection{Goals of Islamic Banking}

The ethical dimension of the Islamic banks makes them more attractive even to non Muslims who are ethically-conscious investors. Islamic banks have a major responsibility to shoulder. The ultimate goal of an Islamic bank is to serve God. The Islamic banks have to build up its own corporate culture, the central purpose of which is to get a collective morality and spirituality which, when combined with the production of goods and services, contribute to the reaching of the major socio-economic goals by emphasizing on the ethical, social and moral elements of wealth creation, with a view to enhancing equality and fairness for the society as a whole.

\section{a. The Social Role and Social Effects of Islamic Banking}

Among the social goals of the Islamic banks, the reduction of inequality between the rich and the poor, the establishment of justice and transparency in all transactions, and the allocation of society's resources to the needy and unfortunate.

The concern over ethical investment is also relevant to Islamic banks. As a business entity established within the respect of the Islamic Law (Shariah), which emphasize, among other, on the principle of social justice and wellbeing.

The several prohibitions such as interest, gambling, excessive risks, etc aim to provide a level of protection of the interests and benefits of all parties involved in market transactions and to promote social harmony.

Islamic banking strives for a just, fair and balanced society as envisioned by the Islamic law.

Islamic banking perform in accordance with their ethics and social responsibility commitment as being more enduring since they are ultimately based on divine revelations.

\section{b. Role of the Islamic banks in alleviating poverty:}

Poverty is seen, from an Islamic point of view, as a threat to human's believes and to the security and stability of the society as a whole. The objectives of Shariah in preserving faith, human soul, progeny, property and mind will be difficult to fulfil in the state of poverty (Note 8). 
These objectives require the provision of basic human needs so that people may not be forced to cross the limits of religion and morality. Islam has made the state as well as the community responsible for reducing poverty from the society.

According to the Islamic principles of social responsibility and justice, Islamic bank must care for the less fortunate in society to maintain equilibrium and social justice.

There are different methods of wealth distribution. One of these methods is called Zakat (tax).Zakat is the wealth tax paid annually on non-working capital, savings, and all types of wealth. It is one of the five basic pillars of Islam (Note 9).

Every Islamic bank thus has to establish a Zakat fund for collecting the tax from investors and depositors and distributing it to the poor. The purpose of the Zakat is to provide the less fortunate with minimum standard of good life.

The mandatory payment of Islamic tax, Zakat: The term 'Zakat' is derived from the Arabic word meaning pure. This tax is one of the five basic tenets of Islam; it is seen as a method for the redistribution of income and wealth among a society to provide equality and a fair standard of living.

The goal of the Islamic bank in alleviating poverty can be achieved by expanding their activities and services into rural areas and small communities, increasing resources mobilization through the collection of Muslims Zakah and Sadaqah and directing them to provide the poor with their basic needs and improving their standard of living.

Zakah and Sadaqah (charity) are two of the main sources of finance for poverty alleviation used by the Islamic banks. Sadaqah is a voluntary act of giving for the cause of God "Allah". Zakat is the yearly obligation of wealthy Muslims to poor and it is the share of the poor in the property and wealth of the rich. It is considered an obligatory form of "charity". It is a fixed proportion collected from the surplus wealth and earnings of a Muslim after subtracting the basic living expenses. Zakah has a deep humanitarian and social-political value.

Islamic banks can play a major role in managing the Zakah and Sadaqah fund which can be used to finance poverty alleviation activities.

Also an equitable wealth distribution can be done through Qard-al-Hasan (benevolent loans) which is a zero return of loan that the Islamic teachings urge Muslim to make available to those who need them. , the borrower then is required to pay-back the principal amount of the loan on maturity without an increment or interest. When no maturity is stipulated, the loan is repaid when asked by the lender, again without any increment. The applicant provides collateral (gold) as security for the principal amount of the loan.

Due to the strong emphasize on the ethical dimensions in Islam such as confidence, solidarity and trust, these loans display high repayment rates.

Besides this, Qard-al-Hasan is used for meeting short-term funding requirements. Whereas some Islamic banks only offer Qard-al-Hasan to clients, who also have investment account with the bank, other banks provide any needy person with this form of an interest-free loan.

\section{c. Purposes of Qard-al-Hasan}

Islam insists on enhancing brotherhood among the Muslims. The main principle of brotherhood is to care about each-others and help other who need money or do not have enough. The main objectives of qard al-hasan are: helping the needy fellow people.

- The elimination of social and economical discrimination from the society trough the establishment of better relationship among poor and the rich.

- The mobilization of wealth among all people in the society which may enhance a helpful society.

- To facilitate the poor to create new jobs market and business ventures by using their merits, skills and expertise and thus eradicates unemployment problem from the society.

Islam intends to establish justice and eliminate exploitation in the society and tries to avoid the accumulation of wealth in the hands of few ones. The Qard al-Hasan as it is an interest free loan for humanitarian and welfare purpose may ensure the proper movement of wealth amongst all classes of people in the society. That is why, the Qur'an and the Sunnah have much emphasized and encouraged for the implementation of Qard al-Hasan in the Muslims society.

\section{Conclusion}

This research is located in the topic area of Ethics and social responsibilities in the financial field with a particular emphasise on the Islamic banking industry.

Islamic finance in general and the Islamic banking particularly can be seen as new ideas and applications to bring ethics and social justice into the financial and economic fields. 
The Islamic financial system has ethical foundations which are based on achieving prosperity and fair distribution of income and wealth among the society.

The principles of Islamic banking were derived from the Shariah law (Islamic law). According to the Islamic finance the ethical investment is based on a moral filter which defines the levels of halal (permissible) and haram (prohibited and undesirable) promoting a positive social climate for society, and providing an expedient legal framework.

In prohibiting transactions based on the interest rate, Islam seeks to establish a society based upon fairness and justice.

Islamic law besides prohibiting the payment and/or collection of interests also prohibits financing activities which conflicts with the moral value system of Islam such as dealing with liquor, pork, gambling, a casino, a night club or any other activity which is prohibited by Islam or known to be detrimental to society and anything which Islamic law deems Haram (unlawful).

One way of manifesting the social role of Islamic banks is the alleviation of poverty by providing finance (through Zakat distribution) to the poor to increase their income and wealth, or by offering Qard-al-Hasan.

The Islamic banks could play an important role in promoting socially desirable investment through its strong emphasis on the ethical and moral dimensions of doing the business and selecting the activities/ commodities to be financed.

Islamic banks have involves various values such as commitment to the social interest, promotion of human welfare, care for the environment and concerns for economic and social justice.

Financial services directed towards helping the poor still limited and do not have significant contribution to poverty alleviation.

This can be improved by expanding the Islamic banking activities into rural areas and small communities and increasing financial resources mobilization through the collection of Muslims' Zakah and Sadaqah which have to be directing to the poor. The Islamic banks could also maintain close contacts with the poor directly and/or indirectly, through its cooperation with other governmental and non-governmental institutions.

\section{References}

El Hawary, D. and Wafik Grais. (2005). "The Compatibility of Islamic Financial Services and Microfinance: A Little-Explored Avenue for Expanding Outreach". NUCDF, Microfinance Issue (14 July, 2005).

Mark S Schwartz. (2003). The "ethics" of ethical investing Journal of Business Ethics; Mar 2003; 43, 3; ABI/INFORM Global pg. 195.

Mashhour, N.(1996). Social and Solidarity Activity in Islamic Banks, International Institute of Islamic Thoughts, [in Arabic].

Rafik Issa Beekun. (1996). November 01, ISLAMIC BUSINESS ETHICS University of Nevada and Islamic Training Foundation

Sirkku Hellsten Chris Mallin. (2006). Are 'Ethical' or 'Socially Responsible' Investments Socially Responsible? Journal of Business Ethics 66: 393-406.

Sparkes, R. ( 2001 ). "Ethical investment: Whose ethics, which investment?" Business Ethics: A European Review, Vol. 10, No. 3, pp. $194-205$.

\section{Internet}

http://www.islamic-banking.com/

http://www.ibisonline.net/

http://www.aaoifi.com/

http://www.iifm.net/

\section{Notes}

Note 1. Mark S Schwartz 2003 The "ethics" of ethical investing Journal of Business Ethics; Mar 2003; 43, 3; ABI/INFORM Global pg. 195

Note 2. Sirkku Hellsten Chris Mallin Are 'Ethical' or 'Socially Responsible' Investments Socially Responsible? Journal of Business Ethics (2006) 66: 393-406.

Note 3. Luc Renneboog Jenke ter Horst Chendi Zhang April 2007 Socially Responsible Investments: Methodology, Risk Exposure and Performance TILEC DP 2007/013 Tilburg University

Note 4. Sparkes , R . (2001) "Ethical investment: Whose ethics, which investment?" Business Ethics: A European Review, Vol. 10 , No. 3 , pp. $194-205$.

Note 5. Rafik Issa Beekun November 01, 1996 ISLAMIC BUSINESS ETHICS University of Nevada and Islamic Training Foundation. 
Note 6. A term literally meaning an excess and interpreted 'as any unjustifiable increase of capital whether in loans or sales'.

Note 7. El Hawary, D. and Wafik Grais, 2005. "The Compatibility of Islamic Financial Services and Microfinance: A Little-Explored Avenue for Expanding Outreach”. NUCDF, Microfinance Issue (14 July, 2005).

Note 8. Mashhour, N., Social and Solidarity Activity in Islamic Banks, International Institute of Islamic Thoughts, 1996 [in Arabic].

Note 9. The five basic pillars of Islam are: (1)- Acceptance of Shahadatane, (2)- Prayer, (3)- Zakat,(4)- Fasting and (5)-Hajj= Pilgrimage to Mecca

\section{Glossary of Islamic Finance Terms}

Quran: the book of revelations from God and taught to the prophet Muhammad "peace be upon him".

Sunnah: the collection of "hadith" describing the Prophet' Muhammad (PBUH) sayings, actions, deeds, approvals and disapprovals. The Sunnah is the most important source of the Islamic faith after the Quran.

Hadith: sayings, deeds and reactions of Prophet Muhammad (PBUH) narrated by his Companions.

Shariah: literally, it means 'a road' refers to Islamic law as ordained by Allah, or the Law of Allah, most include in this category the Quran and Sunnah. Shariah governs both secular and religious life of devout Muslims. It covers religious rituals and many aspects of day-to-day living, politics, economics, banking, and law.

The Shariah is the legal and social modality of a people based on the revelation of their prophet. The last Shariah in history is that of Islam. It abrogates all previous Shari'ahs. It is, being the last, therefore the easiest to follow, for it is applicable to the whole human race wherever they are.

Riba: usury, Increase, addition, expansion or growth. The meaning of this Arabic word is close to the charging of interest, which is forbidden by the Quran. Riba also connotes a loan in which the borrower makes a return to the lender that is more or better than what was borrowed. No financial transaction should be based on the payment or receipt of the interest. Profits from indebtedness or the trading of debts is seen to be unethical. Instead the investor and investee should share in the risks and profits generated from the project.

However, not every increase or growth is prohibited by Islam. Under the Shariah, Riba technically refers to the premium that must be paid without any consideration.

Islamic banking: is a banking system consistent with Islamic law (Shariah) principles and guided by Islamic economics. In particular, Islamic law prohibits the collection and payment of interest. Generally, it also prohibits trading in financial risk (seen as a form of gambling). It also prohibits investing in businesses considered haram (prohibited, forbidden), such as those selling alcohol or pork.

Fatwa: an authoritative legal opinion based on the Shariah law sources.

Halal: permissible

Haram: prohibited

Zakat: obligatory alms. The Muslims' wealth tax: One must pay $2.5 \%$ of one's yearly savings above a certain amount to the poor and needy Muslims. The Zakah is compulsory on all Muslims having wealth above an exemption limit, or have saved (at least) the equivalent of $85 \mathrm{~g}$ of 24 carat gold at the time when the annual Zakah payment is due.

Qard-al-Hasan: A loan granted for welfare purposes or to bridge short-term funding requirements; it could also take the form of a non-remunerated deposit account. The borrower is required to repay only the principal. It's Loans fixed for a definite period of time without interest or profit sharing.

Gharar: Uncertainty, hazard, chance or risk, ambiguity and uncertainty in transactions or in the terms of contract. Technically, the sale of something which is not present at hand or the sale of something where the consequences or outcome is not known. It can also be a sale involving risk or hazard in which one does not know whether it will come about or not, such as fish in water or a bird in the air; or an event where assurance or non-assurance is subject to chance and thus not known to parties of a transaction. Can also mean uncertainty or a hazard that is likely to lead to a dispute in a contract. Consequently is forbidden. Therefore, financial derivatives are usually not permissible under Shariah compliant finance.

Maiser: Gambling. Literally means getting something too easily.

Profit and loss sharing: System where profit and loss are shared between contracting parties.

Sadaqah: is a voluntary act of giving for the cause of Allah: charity.

The ban on unlawful investments: No financial transaction should be directed towards economic sectors considered unlawful with reference to the Shariah, such as tobacco, gambling wine... 